\title{
SEA-ICE AND SNOW-COVER DATA AVAILABILITY, NEEDS
}

\author{
AND PROBLEMS
}

\author{
by \\ R. G. Barry, R. G. Crane, R. L. Weaver and M. A. Anderson \\ (World Data Center A for Glaciology (Snow and Ice), \\ Cooperative Institute for Research in Environmental Sciences, \\ Campus Box 449, University of Colorado, Boulder, Colorado 80309, U.S.A.)
}

\section{ABSTRACT}

Various types of sea-ice and snow-cover data are required for operational purposes in real time, for engineering assessments of associated hazards and for regional to global-scale modeling of the climate system. Data on the primary characteristics of ice and snow (extent, depth or thickness, and ice concentration) are becoming available to meet many present types of modeling requirement but secondary properties such as snow-water content, ridging intensity, open-water fraction and ice drift are less readily available.

Data for these major variables of snow and ice cover are considered with respect to problems encountered in obtaining and using digital information necessary for modern computer analyses. Such problems include the limitations of the basic observations (observational or sensor accuracy), the spatial and temporal resolution of different data sets, varying national practices of observing and reporting, and the problems of meshing data collected by different means and having spatial differences and temporal changes of observation time, site location, sensor system and resolution, etc. The relative reliability and climatic "information content" of some historical data sets are briefly examined and available digital data sets on modern global ice- and snowcover conditions are described.

\section{INT RODUCTION}

Various types of sea-ice and snow-cover data exist at both the regional and global scale. These vary from point observations of snow depth or ice concentration to regional/hemispheric maps of seaice or snow-cover extent, derived primarily from satellite data analys is. Most data sets are produced on an operational basis. An increasing demand for cryospheric data, however, is being felt from the research community. For example, interannual variations in snow-cover and sea-ice extent are being used as an index of climate variability, and data are also required for input to, and validation of, many climate models. In this latter regard, data on the primary characteristics of ice and snow (e.g. snow and ice extent, snow depth) are becoming available to meet many present types of model ing requirements, but data on secondary features such as snowwater content, sea-ice open-water fraction, ridging intensity and ice thickness are less readily available.

Snowfall is routinely measured at meteorological stations, and long-term historical records of snowfall or snow cover have been compiled for a few stations in Europe, east Asia and eastern North America. There has been a longer history of interest in sea ice. I ce off the coast of Iceland has been documented since 860 AD with varying levels of detail and accuracy (Koch 1945). Similarly, west Greenland ice records are available from 1821 and Baltic ice records from the early eighteenth century (Lamb 1977). The most complete global coverage, however, is only available from the early 1960 s with the advent of weather satellites, and more particularly from the early 1970s with the start of the National Oceanic and Atmospheric Administration (NOAA) and Defense Meteorological Satellite Program

(DMSP) series of meteorological satellites.

The present paper describes some of the sea-ice and snow-cover data sets available, concentrating on those that are considered suitable for largescale cryosphere/climate studies. Discussions of problems in data collection, analys is and archiving are also presented with reference to such applications. Detailed descriptions of many of the existing snow and ice data sets are given in publications of the World Data Center A for Glaciology (World Data Center A for Glaciology 1979[a], [b], Crane 1979 . Kukla and others 1981).

\section{THE DATA BASE \\ 2.1. Data streams}

For large-scale climate-related studies the snowcover and sea-ice database can be conveniently divided into long-term (historical) data sets, shorter term data sets derived primarily from satellite analys is that exist in map form, and those data that are available in digital format. Recent discussions of snowcover and sea-ice data have been presented by Barry (in press [a], [b]) and some discussion of cryospheric data in relation to $\mathrm{cl}$ imate modeling has been given by Kotlyakov and Krenke (1982). Both sea-ice and snowcover data are reported by synoptic observation, aerial reconnaissance, satellite and occasionaliy, for sea ice, by submarine remote sensing. The satellite data are primarily from scanning visible and infrared (IR) radiometers and single or multichannel microwave radiometers. While the satellite data are received in digital form, they are usually processed to give some form of imagery, and are then transferred to chart format (Figs.1 and 2). Much attention is now being given to the digitization of such charts. An exception 
to the data interpretation-digitization process is found in the case of sea-ice information derived from the microwave radiometers. These data are presented in the form of gridded brightness temperatures and algorithms are available to convert these into ice concentrations, which are then directly available in a digital format.

\subsection{Historical data}

Snow depth is an indicator of storm frequency, moisture availability, and local factors such as redistribution by wind, compaction, and ablation. The synoptic code has provision for measurements of depth of snow on the ground. These data are collected daily by synoptic stations and reported through the global telecommunications network. These records are not easily retrieved from the high volume synoptic meteorological data archives, but some convenient extracts are available in map form (e.g. US Department of Agriculture 1935-onwards).

The water content of the snowpack is commonly measured by ground surveys for streamflow prediction and flood forecasting. Such data are collected twicemonthly in the United States of America by the Soil Conservation Service on a state-by-state basis. More frequent snowpack data are now available for the western states through the snow telemetry (SNOTEL) network. Data are obtained from approximately 500 remote automatic stations via ionospheric meteor burst telemetry to a central site in Portland, Oregon (Barton and Burke 1979). For Canada, mean snow depth and water equivalent are published for approximately 1300 snow courses (Canada Atmospheric Environment Service 1961-onwards). Other regional snow-cover data sets have been produced for Austria (Hydrographischer Dienst in Osterreich 1962), Great Britain (Crane 1979) and the Soviet Union (Crane 1979). Snowcover data are also collected in many mountain ranges in connection with avalanche prediction and hydroelectric programs, as well as for programs of winter orographic cloud seeding. These records, however, are not usually available in accessible archives.

Some historical sea-ice records were mentioned in the introduction. Monthly ice charts for April to the end of the ice season (August or September) for the years 1901 to 1939 and 1946 to 1956 have also been published for the Arctic Ocean by the Dansk Meteorologisk Institut (1901(?)-1959). These data are available in digital form from 1901 (Kelly 1979). Several regional charts are available based usually on mixed satellite, aircraft and some surface observations. Such local data sets are produced by Canada, Norway, Finland, West Germany, Sweden, and Japan. Ice charts for the Soviet Arctic have been prepared since 1937 (Crane 1979). Little information is known, however, concerning the availability of the Soviet products.

\subsection{Satellite data}

Satellite data have been available since the early 1960s. Sensors and analys is systems, however, have been continuously upgraded since this time. Consistent coverage has only been available since the early 1970s with the launch of the National Oceanic and Atmospheric Administration (NOAA) series of satellites, and with the introduction of a passive microwave radiometer on board Nimbus-5. Being unaffected by clouds or the polar night, this sensor allowed, for the first time, the possibility of continuous all-weather synoptic analyses of sea-ice distribution.

The National Environmental Satellite Data and Information Service (NESDIS) has mapped northern hemisphere snow and ice boundaries since 1966. Three classes of surface reflectivity are mapped on a weekly basis. Before 1970 the analys is was based on visible data from the Advanced Vidicon Camera System (AVCS) and the Automatic Picture Transmissions (APT) on the ESSA satellites. Thermal IR data were added with the introduction of the scanning radiometer data from
ItOS-1, and increased resolution was obtained from the Very High Resolution Radiometer (VHRR) with the launch of NOAA-2 in October 1972. The most cons istent data are those obtained from 1974 onwards (Kukla and Robinson 1981). A11 of the weekly snow and ice charts from 1966 to 1980 , as well as monthly summaries, are now available in a digital format (Dewey 1981).

NOAA VHRR data have also been used by the US Navy to map sea-ice extent and concentration since 1972 for the northern hemisphere, and from 1973 for the southern hemisphere. Electrically Scanning Microwave Radiometer (ESMR) data from Nimbus 5 and 6 were routinely incorporated into the analyses from December 1972 to September 1976. Since October 1977 DMSP $v$ isible and IR data have also been used when available. Production of these charts was taken over by the US Navy-NOAA Joint I ce Center in June 1979.

The microwave radiometer data from $N$ imbus 5 and 6 have also been used experimentally to map continental snow cover (Hall and others 1979). Techniques are being developed to use both passive and active microwave data to estimate snow depth or snow water equivalent, wetness and snowpack structure (Rango 1980). In this regard, research is presently being conducted using Scanning Multichannel Microwave Radiometer (SMMR) data from Numbus 7 .

Several years of SMMR data will also be available for mapping sea-ice concentration, the fraction of multiyear ice, and the surface ice temperature on a six-day basis. Sensor systems have been developed that could provide information on many of the secondary sea-ice characteristics (Table I). Detailed information on ice morphology, ridging intensity, leads and fractures, and ice drift are becoming more vital for model validation as the complexity of cryospheric and atmospheric models increase. However, few data of this type have been collected.

\subsection{Digital data products}

Several sets of digitized snow and ice data are now available. Walsh (1978) has extracted northern hemisphere ice concentration values for 1953 to 1977 on a $110 \mathrm{~km}$ grid, using a variety of sources (Crane 1979). From 197.2 the source used was primarily the week ly Navy-NQAA ice charts. The same grid was used by Kelly (1979) for the digitization of the Danish Meteorological Institute ice charts.

Lemke and others (1980) have digitized the monthly ice charts of the British Meteorological office for the Arctic, 1966-1976, and the week ly US Navy charts for Antarctica, 1973-1979. For the northern hemisphere, the parameter given is the area of ice per $10^{\circ}$ longitude $\times 1^{\circ}$ latitude sector, and, for Antarctica, it is the latitude of $>5 / 8$ ice concentration per $5^{\circ}$ longitude sector. Arctic and Antarctic ice concentrations and northern hemisphere snow cover have also been digitized, in geographic sectors, for various time periods by Kukla and Gavin (1979).

A further digital sea-ice data set exists in the form of ESMR microwave brightness temperatures. The most continuous period for which data are available is from September 1973 to December 1974. In the northern hemisphere, the set cons ists of gridded brightness temperatures on a 293 × 293 matrix, overlying a polar stereographic projection centred on the pole. For the southern hemisphere, the format is the same, but the data are also given as concentration classes in $4 \%$ intervals. An atlas of four years of Antarctic sea-ice concentrations has been prepared for 1973-1976 (see Zwally and others 1981).

\section{DATA PROBLEMS}

Problems occur both in the collection of the original data and in the compositing of different data sets into a climatological archive. In terms of the data collection, limitations are found in the basic observations (observational or sensor accuracy), and in methods of data analysis. When attempting to 


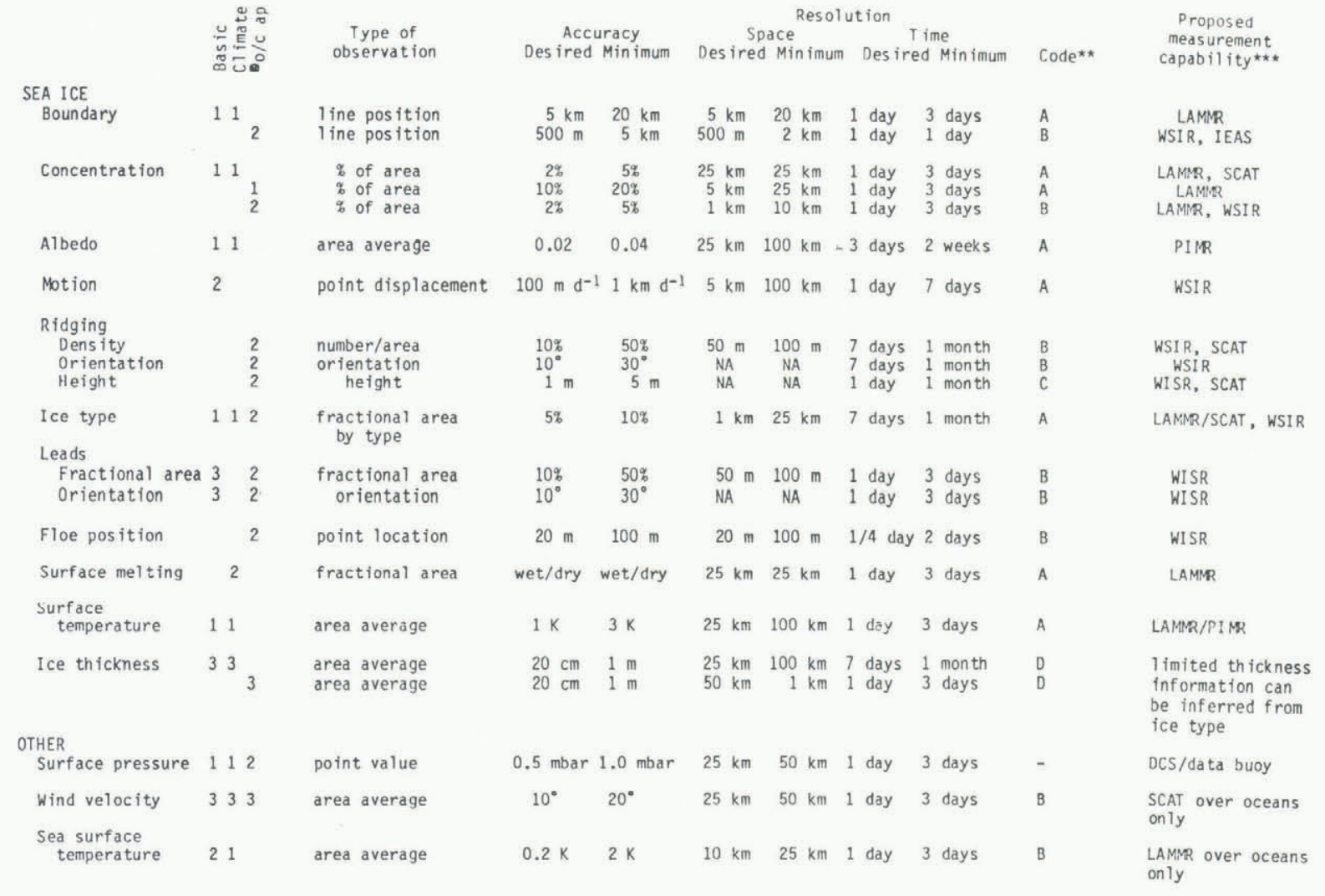

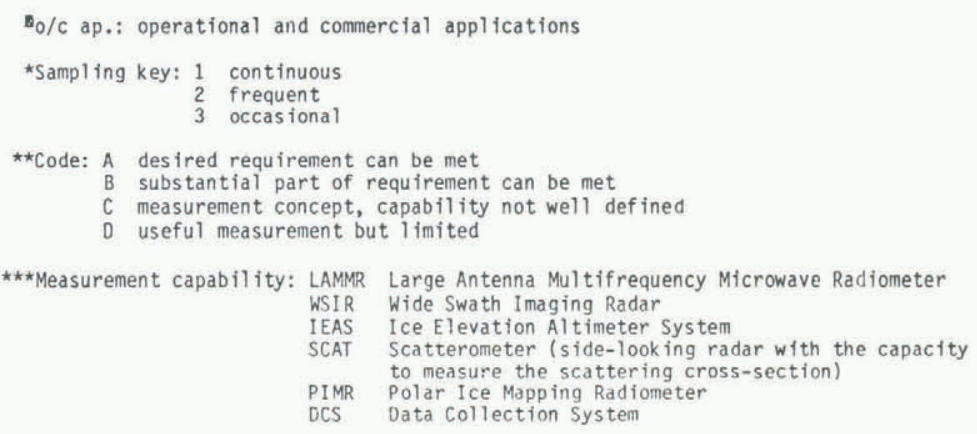

composite different sources into a climatological data set, problems are also encountered in meshing data collected at different spatial and temporal resolutions. One of the major problems, particularly with regard to the large-scale global data sets, is the frequent lack of internal homogeneity brought about by changes in observation procedures with time.

\subsection{Problems of data collection}

Kukla and Robinson (1981) compared the operational snow- and ice-cover charts produced by NOAA-NESS and by the US Navy-NOAA Joint I ce Center with ground station reports and original satellite imagery. From 1974 the NOAA-National Earth Satellite Service (NESS) reflectivity charts were found to be sufficiently accurate (in terms of the location of cryospheric boundaries) for large-scale climate studies. The reflectivity classes were also adequate for hemispheric studies, but not for those at the regional scale. Before 1974, however, large discrepancies were found in the snow-cover charts for autumn, and reflectivity classes were found to be inadequate throughout the year. Much of this error is attributed to errors occurring in regions of pers istent cloud cover, a situation frequently found in middle and high latitudes in autumn. Problems in determining the areal snow extent are also found in mountainous regions, and in forest. Kukla and Robinson (1981) point out that a dense coniferous forest with a dark canopy may show very little difference between summer and winter, even with $30 \mathrm{~cm}$ of snow on the ground. The Navy-NOAA ice charts were found to be a good representation of ice extent and concentration, al though thin ice was frequently not differentiated from open water.

Problems in image interpretation also occur when using conventional visible and IR satellite data due to the difficulty in distinguishing between snow/sea ice and cloud cover. Differentiation between snow/ice and cloud is complicated by the similarity of their radiative temperatures (particularly in the case of of low cloud), and by the similarity of their spectral reflectance in the visible wavelength. Experimental work with laboratory and both aircraft and satellite observations show that automated discrimination between snow or ice and cloud is possible in the near IR (Bunting and Entremont 1982, Scharfen and Anderson 1982), but sensors such as these will 
not be in operational use until the next generation of meteorological satellites is launched.

Microwave radiometer data from Nimbus 5 and 6 are available during the polar night and are essentially unaffected by cloud cover; as such they have proved very useful in determining the position of the ice edge. The microwave brightness temperature received by the satellite, however, is a function of the surface temperature, the amount of open water in the field of view, and the emissivity of the near surface layer of the ice. The emissivity varies primarily as a function of the salinity of the ice, which is inversely correlated with age. The inability to resolve these separate effects quantitatively may lead to large errors in the estimate of ice concentration, and illustrates the major problem with the use of the single channel data (two channels in the case of Nimbus 6 ). In this respect, considerable improvement is anticipated from the multi-channel (SMMR) microwave data from Nimbus 7 . These data, available from 1979, are now being processed.

In attempting to construct a long-term data set suitable for climatological analysis, a major prob$7 \mathrm{em}$ of ten occurs due to the inhomogeneity with in the data source. Walsh (1978), for example, has produced a 25-year digital set of monthly sea-ice data on a $110 \mathrm{~km}$ grid, showing ice concentration at $1 / 10$ intervals. The data sources, their spatial and temporal resolution, and their reliability, vary considerably over the 25-year period (Table II). Table III shows the satellites and sensor systems used in the NOAA-NESS snow and ice boundary analyses since 1966. In this case the data set is based entirely on satellite observations, but again sensors employed have undergone considerable development with time.

\subsection{Problems of data compilation}

Some of the difficulties involved in the production of climatological archives arise from the fact that most sea-ice/snow-cover analyses are performed on an operational basis. Several consequences of this approach are apparent. For example, because of time constraints not all of the potential data sources are necessarily included in the analys is, and there is little opportunity for quality checking of the data or products. Where different data sources are used, there is usually no indication in the final product of which data sources were used, nor to how much of the analys is they contributed. An exampl\& can be seen in the case of the US Air Force snow depth model (SNODEP). The model outputs global snow depths for a grid superimposed on a polar stereographic projection (grid spacing is 25 nautical miles $(46 \mathrm{~km}$ ) at $60^{\circ} \mathrm{N}$ and S). Snow depths are given in six categories from $<5$ to $>25 \mathrm{~cm}$ and the analys is is updated on a daily basis. The model inputs include station observations of snow depth, precipitation, and temperatore, ice cover from the weekly Navy-NOAA charts, and satellite analysis. Missing data are filled from cl imatology. No information is given, however, on the data source for any given grid point and time. Kukla and Robinson (1981) find that the model tends to overestimate snow-cover extent, and suggest that these data may be less suited for climate-related studies involving albedo than the NOAA charts for most of the year. They also note, however, that the model may provide the best operational source of snow-extent data in autumn, and the quality of the data has improved over time (data are available from 1967 to the present).

A related problem is found in maps composited over several days. In this case it is usually impossible to determine which regions were mapped on any particular day. Most of the satellite-derived operational snow and ice charts fall into this category, as do the three-day composited images produced from the ESMR data. This may not pose a problem for hemispheric-global scale studies, where a weekly time step may be sufficient; it would become increasingly important, however, for analyses at smaller regional scales.

\subsection{Problems of data management}

As ide from the problems of data compilation that have already been discussed, several problems can be mentioned that are common to many data management tasks. For example, cryospheric data are fragmented

TABLE II. DESCRIPTION OF DATA SOURCES USED FOR THE WALSH (1978) SEA-ICE DATA SET (from CRANE 1979)

\begin{tabular}{|c|c|c|c|c|c|c|c|c|c|c|c|c|c|c|c|}
\hline \multirow[t]{4}{*}{ Source } & \multirow{4}{*}{$\begin{array}{l}\text { Time } \\
\text { from }\end{array}$} & \multirow{4}{*}{$\begin{array}{l}\text { period } \\
\text { to }\end{array}$} & \multirow{4}{*}{$\begin{array}{l}\text { Time interval } \\
\text { between } \\
\text { successive } \\
\text { products }\end{array}$} & \multirow{2}{*}{\multicolumn{2}{|c|}{$\begin{array}{l}\text { Smallest homogeneous area } \\
\text { that can be resolved by } \\
\text { mapping/digitizing system } \\
\text { of data source* }\end{array}$}} & \multirow{4}{*}{$\begin{array}{l}\text { Distance within } \\
\text { which plotted } \\
\text { snow/ice bound- } \\
\text { aries are accur- } \\
\text { ate under typical } \\
\text { conditions } \\
\quad(\mathrm{km})\end{array}$} & \multicolumn{9}{|c|}{ Consistency between maps in } \\
\hline & & & & & & & \multirow{2}{*}{\multicolumn{6}{|c|}{$\begin{array}{l}\text { the identification } \\
\text { of the minimum } \\
\text { resolvable area } \\
\text { under } \\
\text { worst under } \\
\text { conditions condical } \\
\text { typions }\end{array}$}} & \multirow{2}{*}{\multicolumn{3}{|c|}{$\begin{array}{l}\text { the accuracy } \\
\text { of the } \\
\text { boundaries }\end{array}$}} \\
\hline & & & & \multirow{2}{*}{$\begin{array}{c}\text { under } \\
\text { worst } \\
\text { conditions } \\
\left(\times 10^{3} \mathrm{~km}^{2}\right)\end{array}$} & \multirow{2}{*}{$\begin{array}{c}\text { under } \\
\text { typical } \\
\text { conditions } \\
\left(\times 10^{3} \mathrm{~km}^{2}\right)\end{array}$} & & & & & & & & & & \\
\hline & & & & & & & ڤั & $\frac{5}{2}$ & : & & $\frac{1}{\pi}$ & : & ؛े & $\frac{5}{\pi}$ & : \\
\hline $\begin{array}{l}\text { US Navy Fleet } \\
\text { Weather Facility }\end{array}$ & $1 / 72$ & $12 / 77$ & 1 week & 100 & 2.5 & $20-30$ & & $x$ & & & & $x$ & & & $x$ \\
\hline US Navoceano & $1 / 53$ & $12 / 71$ & $\begin{array}{l}1 \text { week to } \\
\text { several months }\end{array}$ & 250 & 4.0 & $\begin{array}{l}20-30 \\
\text { (when not estimated) }\end{array}$ & $x$ & & & & & $\mathrm{x}$ & & & $x$ \\
\hline $\begin{array}{l}\text { British Meteoro- } \\
\text { logical office }\end{array}$ & $6 / 59$ & $12 / 77$ & 1 month & 250 & 6.5 & $50-75$ & $x$ & & & & $x$ & & & $x$ & \\
\hline $\begin{array}{l}\text { Danish-Greenland } \\
\text { waters }\end{array}$ & $1 / 57$ & $12 / 64$ & $\begin{array}{l}1 \text { week to } \\
\text { several months }\end{array}$ & 250 & 2.5 & $\begin{array}{l}20-30 \\
\text { (when not estimated) }\end{array}$ & $x$ & & & & & $x$ & & & $x$ \\
\hline $\begin{array}{l}\text { Danish-Arctic } \\
\text { seas }\end{array}$ & $4 / 53$ & $12 / 56$ & $\begin{array}{l}1 \text { month } \\
\text { (sumner only) }\end{array}$ & 400 & 9.0 & $50-75$ & $x$ & & & & $x$ & & & $x$ & \\
\hline Canadian & $5 / 64$ & $11 / 69$ & $\begin{array}{l}1-2 \text { weeks } \\
\text { (summer only) }\end{array}$ & 25 & 2.5 & $10-20$ & & & $x$ & & & $x$ & & & $x$ \\
\hline I celandic & $1 / 53$ & $12 / 67$ & $\sim 1+$ months & 25 & 4.0 & $\sim-50$ & & $x$ & & & & $x$ & & $x$ & \\
\hline Norwegian & $1 / 63$ & $12 / 71$ & 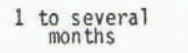 & 25 & 4.0 & $\sim-40$ & $x$ & & & & & $x$ & & $x$ & \\
\hline
\end{tabular}


Barry and others: Sea-ice and snow-cover data availability

TABLE III. SATELLITES AND SENSORS USED IN MAPPING NORTHERN HEMISPHERE SNOW AND ICE COVER (from CRANE 1979)

\begin{tabular}{|c|c|c|c|c|}
\hline Satellite & Sensor* & $\begin{array}{l}\text { Spectral band } \\
(\mu \mathrm{m})\end{array}$ & $\begin{array}{l}\text { Subpoint resolution } \\
\qquad(\mathrm{km})\end{array}$ & Period of operations \\
\hline $\begin{array}{ll}\text { ESSA } & 3 \\
\text { ESSA } & 4 \\
\text { ESSA } & 7 \\
\text { ESSA } & 8 \\
\text { ESSA } & 9 \\
\text { ITOS } & 1\end{array}$ & $\begin{array}{l}\text { AVCS } \\
\text { APT } \\
\text { AVCS } \\
\text { APT } \\
\text { AVCS } \\
\text { AVCS } \\
\text { APT } \\
\text { SR }\end{array}$ & $\begin{array}{r}0.5-0.75 \\
0.5-0.75 \\
0.5-0.75 \\
0.5-0.75 \\
0.5-0.75 \\
0.5-0.75 \\
0.5-0.75 \\
0.52-0.73 \\
10.5-12.5\end{array}$ & $\begin{array}{l}3.7 \\
3.7 \\
3.7 \\
3.7 \\
3.7 \\
3.7 \\
3.7 \\
3.7 \\
7.4\end{array}$ & $\begin{array}{r}2 \text { October } 1966 \text { - } 9 \text { October } 1968 \\
26 \text { January } 1967-6 \text { December } 1967 \\
15 \text { August } 1968 \text { - } 19 \text { July } 1969 \\
15 \text { December } 1968 \text { - } 12 \text { March } 1976 \\
26 \text { February } 1969-15 \text { December } 1973 \\
23 \text { January } 1970-17 \text { June } 1971\end{array}$ \\
\hline NOAA 2 & $\begin{array}{l}\text { VHRR } \\
\text { SR }\end{array}$ & $\begin{array}{l}0.6-0.75 \\
10.5-12.5 \\
0.52-0.73 \\
0.50-0.94 \star \star \star \\
10.5-12.5\end{array}$ & $\begin{array}{r}1-1.9 \\
1-1.9 \\
3.7 \\
3.7 \\
7.4\end{array}$ & 15 October 1972 - 30 January 1975 \\
\hline NOAA 3 & $\begin{array}{l}\text { VHRR } \\
\text { SR }\end{array}$ & $\begin{array}{l}0.6-0.75 \\
0.52-0.73 \\
10.5-12.5\end{array}$ & $\begin{array}{r}1-1.9 \\
3.7 \\
7.4\end{array}$ & 6 October 1973 - present \\
\hline NOAA 4 & $\begin{array}{l}\text { VHRR } \\
\text { SR }\end{array}$ & $\begin{array}{l}\text { Same as NOAA } 3 \\
\text { Same as NOAA } 3\end{array}$ & & 15 November 1974 - present \\
\hline NOAA 5 & $\begin{array}{l}\text { VHRR } \\
\text { SR } R^{\star \star \star}\end{array}$ & $\begin{array}{r}0.6-0.75 \\
10.5-12.5 \\
0.52-0.73 \\
0.50-0.94 \\
10.5-12.5\end{array}$ & $\begin{array}{r}1-1.9 \\
1-1.9 \\
3.7 \\
3.7 \\
7.4\end{array}$ & 29 July 1976 - present \\
\hline $\begin{array}{l}\text { SMS-1 } \\
\text { (GOES) }\end{array}$ & VISSR & $\begin{array}{l}0.55-0.70 \\
10.5-12.5\end{array}$ & $\begin{array}{r}1-7.4 \\
7.4-14.8\end{array}$ & 17 May 1974 - present \\
\hline
\end{tabular}

* Camera and sensors: AVCS: Advanced Vidicon Camera System; APT: Automatic Picture Transmissions; SR: Scanning Radiometer; VHRR: Very High Resolution Radiometer; VISSR: Visible and Infrared Spin Scan Radiometer.

** SR failed 3 March 1974.

$\star \star \star$ SR failed 16 March 1978.

\section{SNOW COVER DATA STREAMS}
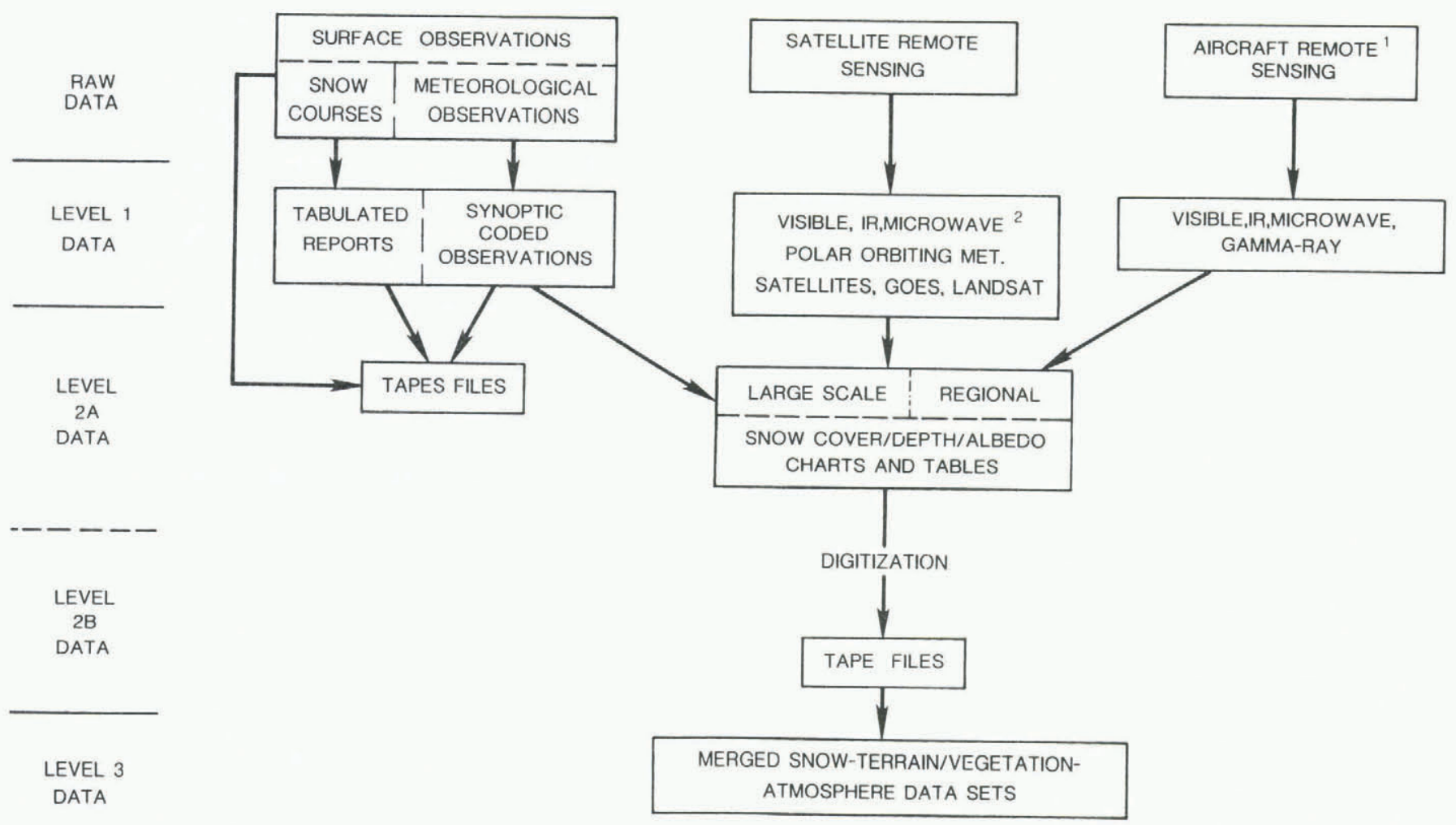

LEVEL 3

DATA

$$
\text { ATMOSPHERE DATA SETS }
$$

1 Primarily in a research mode, or operational at the 1 ocal/regional scale.

2 The microwave is used primarily in a research mode.

Fig.1. Snow-cover data streams. 


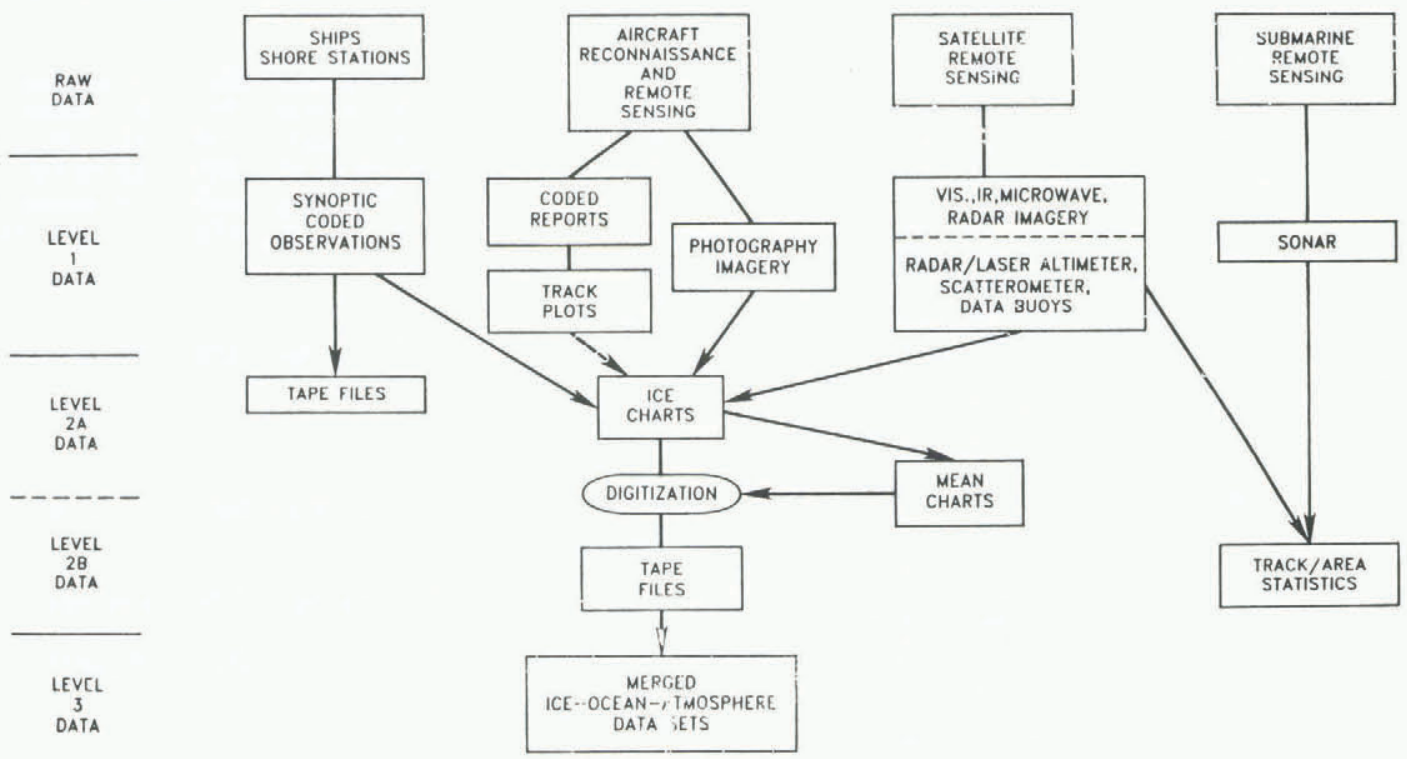

Fig.2. Sea-ice data streams (Barry in press [a]).

by region with no single agency being responsible for gathering them together. In many cases, data are not put out in a form that can be readily used by the researcher. Snow and ice data are frequently presented in chart format, whereas most research purposes would require some form of numerical gridded data.

The user community of ten has great difficulty in determining what data are available and what information exists concerning their quality and possible 1 imitations. Frequently, there are also long delays between the receipt of data on the ground and the delivery of preprocessed data to the user. An example of this is the SMMR data for 1979, which are only now becoming generally available.

A growing demand is also being felt for the development of level 3 data sets (Figs.1 and 2). Very few merged data sets are available at present. Exceptions can be found in the Arctic Ice Dynamics Joint Experiment (AIDJEX), and the current Marginal I ce Zone Experiment (MIEX). In both cases large amounts of concurrent sea-ice, atmospheric and oceanic data have been collected, but both experiments are of a limited time span and data are only for relatively small geographic regions. Merged data sets are also necessary at the hemispheric or global scale. Considering all these problems, there is an obvious need for the development of a comprehensive data management system that would provide a multi-disciplinary polar research data set.

4. SUMMARY AND CONCLUSIONS

Information on the primary characteristics of sea ice and snow cover are becoming available in a format to suit most large-scale climate studies and, following the launch of the NOAA series of satellites in the early 1970s, there is now at least ten years of reasonably cons istent data. With regard to sea ice, steps are now being taken to derive a uniform approach to the formatting of gridded data. For snow cover, on the other hand, more attention needs to be paid to the standardization of analys is methods and data presentation (cf. recommendations of the workshop on snow cover and sea ice data (World Data Center A for Glaciology 1979[b], Kuk la and others 1981).

The future is likely to see continued improvements in the accuracy and resolution of satellite derived sea ice and snow cover boundaries. Sensors are also being developed which will aid in snow/cloud discrimination and which may provide some of the secondary features of the snow/ice cover such as snow depth/water equivalent, ice thickness, morphology, open water fraction, etc. It will be some time, however, before such data can be collected on a rout ine bas is.

Multichannel microwave data will be a primary source of sea-ice and possibly snow-cover data for the remainder of the decade, and these data will be prime candidates for integration into a unified product. A data management system developed for the microwave data could also be readily expanded to include data from existing digital data sets, data collected from experiments such as MIZEX, future satellite-derived cryospheric data such as those that may be developed from the Synthetic Aperture Radar (SAR), and other ancillary data. These ancillary data could include the Arctic 0cean buoy data as well as other synoptic meteorological observations. If expanded to its full potential, such a management system would provide a single integrated access point for most cryospheric satellite and ground-based data sets.

\section{ACKNOWLEDGEMENT}

This work was supported under NASA Contract NAGW-1846.

\section{REFERENCES}

Barry $R G$ In press[a] The data base. In Untersteiner $\mathrm{N}$ (ed) The geophysics of sea $i c e$. New York, Plenum

Barry $R$ G In press[b] Snow and ice data. In Hecht A D (ed) Paleoclimate data analysis and modeling. New York, John Wiley and Sons

Barton M, Burke M 1979 SNOTEL: an operational data acquisition system using meteor burst technology. Glaciological Data Report GD-6: 59-69

Bunting J T, Entremont R P d' 1982 Improved cloud detection utilizing Defense Meteorological Satellite Program near infrared measurements. Hascom AFB, MA, Air Force Geophysics Laboratory (AFGL-TR-82-0027) 
Canada. Atmospheric Environment Service 1961 onwards Snow cover data. Downsview, Ontario, Environment Canada

Crane R G (comp) 1979 Inventory of snow cover and sea ice data. Glaciological Data Report GD-7

Dansk Meteorologisk Institut 1901(?)-1959 The state of the ice in the Arctic seas, 1901-1956. Charlottenlund, Dansk Meteorologisk Institut (appendix to Nautical-Meteorological Annual)

Dewey K F 1981 Snow cover digital products. Glacio logical Data Report GD-11: 129-133

Hall D K, Foster J L, Chang A T C, Rango A 1979 Passive microwave applications in snowpack monitoring using satellite data. NASA. Technical Memorandum 80310: 10

Hydrographischer Dienst in Osterreich 1962 Der Schnee. in Osterreich im Zeitraum 1901-1950. Beiträge zur Hydrographie Österreichs 34

Kelly P M 1979 An Arctic sea ice data set, 19011956. Glaciological Data Report GD-5: 101-106

Koch L 1945 The East Greenland ice. Meddelezser om Gronizand 130(3)

Kotlyakov V M, Krenke A N 1982 Data on snow cover and glaciers for the global climatic models. In Eagleson P S (ed) Land surface processes in atmosphemic general circulation models. Papers presented at the World Climate Research Programme study conference....Greenbelt, Maryland...1981. Cambridge etc, Cambridge University Press: 449-461

Kukla G, Gavin J 1979 Snow and pack ice indices. Glaciological Data Report GD-6: 9-14

Kukla G, Robinson D 1981 Climatic value of operational snow and ice charts. Glaciological Data Report GD-11: 103-119

Kukla G, Hecht A, Wiesnet D (eds) 1981 Snow watch 1980. Glaciological Data Report GD-11

Lamb H H 1977 Climate: present, past and future. Vol 3. Climatic history and the future. London, Methuen.

Lemke P, Trink1 E W, Hasselmann K 1980 Stochastic dynamic analys is of polar sea ice variability. Joumal of Physical Oceanography 10(12): 2100-2120

NASA 1979 ICEX. Ice and climate expemiment. Greenbelt, MD, Goddard Space Flight Center

Rango A (ed) 1980 Microwave remote sensing of snowpack properties. Proceedings of a workshop... held at Fort Collins, Colonado... 1980. Washington, DC, National Aeronautics and Space Administration (NASA Conference Publication 2153)

Scharfen G R, Anderson M R 1982 Climatic applications of a satellite snow/cloud discrimination sensor. Westerm Snow Conference. Proceedings: 92-101

United States. Department of Agriculture 1935 onwards Weekly Weather and Crop Bulletin. Washington, DC, Agricultural Weather Facility

Walsh J E 1978 A data set on northern hemisphere sea ice extent, 1953-1976. GLaciological Data Report GD-2, Part 1: 49-51

World Data Center-A for Glaciology 1979[a] Snow cover. Glaciological Data Report GD-6

World Data Center-A for Glaciology 1979[b] Workshop on snow cover and sea ice data. Glaciological Data Report GD-5

Zwally H J, Comiso J C, Parkinson C L 1981 Satellitederived data sets No.1: Antarctic monthly average microwave brightness temperatures and sea ice concentrations 1973-1976. NASA. Technical Memorandion 83812 